\title{
The effects of different types of bedding on the performance, skeletal and behavioral characteristics, hygienic and immunity conditions of suckling Holstein calves
}

\author{
S. M. J. Hosseini, T. Tanha* and H. Maghsoodi \\ Department of Animal Science, Faculty of Agriculture, \\ Payame Noor University, Tehran, Iran \\ *Corresponding E-mail: t.tanha@pnu.ac.ir
}

Received February 22, 2021; Accepted July 10, 2021

\begin{abstract}
ABSTRAK
Kajian menginvestigasi pengaruh jenis alas kandang pada kinerja, karakteristik kerangka dan perilaku, kondisi kesehatan dan kekebalan pedet sapi Holstein yang menyusui, percobaan dilakukan dalam desain acak lengkap menggunakan 80 pedet sapi Holstein. Pedet sapi dibagi menjadi 5 perlakuan dan 4 ulangan (setiap ulangan terdiri dari 2 ekor jantan dan 2 ekor betina). Lima perlakuan percobaan adalah sekam, jerami, ampas tebu, pasir, atau "mat". Hasil penelitian menunjukkan bahwa konsumsi pakan tertinggi terdapat pada pasir dan alas sekam dan pertambahan bobot tertinggi terdapat pada sekam, jerami dan sandbedding $(\mathrm{P}<0,05)$. Tinggi layu tertinggi dan terendah masing-masing untuk perlakuan jerami dan tikar $(\mathrm{P}<0,05)$. Waktu berdiri dan istirahat terpanjang dalam perilaku pedet sapi ditemukan untuk perlakuan pasir dan jerami, masing-masing $(\mathrm{P}<0,05)$. Pada skor kebersihan, hidung, mata, dan sendi, jumlah kontaminasi tertinggi terkait dengan perlakuan "mat" dan pasir $(\mathrm{P}<0,05)$. Untuk parameter imunitas, perlakuan ampas tebu menunjukkan kadar eosinofil paling tinggi dibandingkan perlakuan lainnya $(\mathrm{P}<0,05)$. Hasil penelitian menyimpulkan bahwa alas kandang jerami memiliki karakteristik pertumbuhan, perilaku, dan kesehatan pedet yang lebih baik dibandingkan dengan jenis alas kandang lainnya.
\end{abstract}

Kata kunci: Pedet Holstein, Alas kandang, Imunitas, Perilaku, Performa.

\begin{abstract}
To investigate the effects of bedding types on the performance, skeletal and behavioral characteristics, health and immunity conditions of suckling Holstein calves, an experiment was conducted in a completely randomized design using 80 Holstein calves. The calves were distributed over 5 treatments and 4 replicates (each replicate included 2 male and 2 female calves). The 5 experimental treatments werechaff, straw, bagasse, sand, or mat. The results showed that the highest feed intake was related to the sand and chaff beddings and the highest weight gain $(\mathrm{P}<0.05)$ was found for the chaff, straw and
\end{abstract}


sandbeddings . Withers height was highest and lowest for straw and mat treatments, respectively $(\mathrm{P}<0.05)$. The longest standing and resting times in calf behavior $(\mathrm{P}<0.05)$ were found for the sand and straw treatments, respectively. In cleanness, nose, eye, and joint scorings, the highest amount of contamination was related $(\mathrm{P}<0.05)$ to the mat and sand treatments. For immunity parameters, bagasse treatment showed the highest level of eosinophils $(\mathrm{P}<0.05)$ compared to the other treatments. According to the results, it can be concluded that the straw bedding has better characteristics for growth, behavior, and health of calves compared to the other beddings.

Keywords: Holstein, Bedding, Immunity, Behavior, Performance.

\section{INTRODUCTION}

Farm animal welfare has always been one of the most important issues in the field of animal sciences. Paying attention to animal welfare is very effective in reducing diseases and their consequences and thus affecting the economic outcome (Ahmadi et al., 2019; Poorghasemi et al., 2017).

In this regard, studies have proposed several indicators for animal well-being. Design, size and type of bedding, floor type of stand and corridors, stand cleanness, livestock behavior and social interactions, management, livestock density in the stand, weather conditions and heat stress, ventilation, amount of walkway area, manger, and drinking place are among the indicators (Slozhenkina et al., 2020; Ahmadi et al., 2018; Poorghasemi et al., 2013). Suckling calves are no exception. Each farm has a section for keeping calves, which should have some characteristics to provide livestock comfort (Boujenane, 2019; Leach et al., 2015). To create livestock comfort, different factors such as the type of bedding, the dimensions of the stand, proper ventilation, proper feed, etc. must be considered. Each of these factors has direct effects on the life quality of calves (PirzadehNaeiny et al., 2019). Bedding is one of the most important factors affecting calf growth. In general, beddings are divided into organic and inorganic groups. Straw, sawdust, wood chips, bagasse, and dry manure are among the organic beddings (Meng et al., 2015). The main disadvantage of this type of beddings is the rapid growth of bacteria due to increased moisture. The presence of moisture, which is one of the conditions for the growth of microbes, causes a rapid increase in bacteria in this type of bedding in 24 hours (Meng et al., 2015).

In these types of beddings, the particle size of the bedding constituents is also important because the smaller the particles, the more the bedding material comes into contact with the animal's body and causes more bacteria to be transferred to the animal (Eklind and Kirchmann, 2000).

Inorganic beddings include sand, rubber mattresses and beddings, which can be the best bedding for livestock from a microbiological point of view. The advantages of this types of beddingare the absence of carbon and nitrogen, which help the growth of microbes, low capacity to retain moisture and their soft tissue, which provides comfort for livestock (Eklind and Kirchmann, 2000).

Regarding the advantages and disadvantages of inorganic beddings, various cases have been mentioned, the most important of which is poor management regarding buying the proper inorganic bedding and also lack of knowledge on how to manage its use in livestock resting areas (Eklind and Kirchmann, 2000).

Different factors such as the type of bedding, the dimensions of the place, proper ventilation and proper feed should be considered to create livestock comfort. Each of these factors has a direct impact on the quality of life of the calf. The bedding is one of the most effective factors that affect the growth of calves. In addition to the importance of bedding type for cleaning, drying, and keeping calves comfortable and healthy, how 
ence in the amount of weight at the end of the breeding period of each calf from the birth weight was divided by the number of days spent in the period. Finally, the feed conversion ratio for each calf was obtained by dividing the feed intake of the entire period by the amount of body weight gain in the entire period.

\section{Measurement of Skeletal Characteristics}

The criteria including body length, chest circumference, abdominal circumference, withers height, and pelvic width were used to measure skeletal characteristics. Body length was measured from the front part of the humero radial joint of the elbow to the pin bone (the prominent pelvis part of the tuber coxae). Measurement of chest circumference was performed exactly from the olecranon joint of the elbow so that the meter rotated in a complete oval around the front ribs and then the number was recorded. Abdominal circumference was measured as an oval from the end of the ribs. The height of the calf was measured from the withers area with the calf standing straight with its head up. Two pelvic bulges of the wing of ilium bones were used to measure pelvic width, regardless of the bulge in the area where the tail grows (Sharifi et al., 2017).

\section{Behavior}

Calf behavior was recorded to assess the activity and well-being of the calves. Behaviors were examined in nutritional and non-nutritional contexts. Nutritional behaviors included duration of feed intake, duration of water drinking, milk drinking, and non-nutritional behaviors including sitting, standing, resting, and bucket licking. Behavioral studies of calf behaviors for each treatment were recorded on days $15,16,30,31,60$, and 61 . The measurements were taken every 5 minutes for 8 hours per day from 9 am to $5 \mathrm{pm}$ to include one milk feeding in the schedule (Seifzadeh et al., 2019).

\section{Hygiene Status of Calves}

At this stage, scoring on cleanness, eye health, ear health, nose health, cough condition, and scratch condition in the hock joint area was performed on days $1,15,30$, and 60 . Scores were were on a scale from 0 to 3 . The cleanness score of 0was assigned toa clean back, thighs, and hooves free of feces; the cleanness score of 1 was assigned to a partial or no smeared back, low smeared thighs and hooves; the cleanness score of 2 was assigned to a $2 / 3$ smeared thighs and hooves as well as the pelvis; the cleanness score of 3 was assigned to a complete smeared hooves and thighs so that the cover of the body was not visible and the back of the calf was completely smeared with feces. For eye scoring, the score of 0 was assigned to two healthy and transparent eyes free of any infection; the score of 1 was assigned to colorless tear discharges that cause wetting around the calf's eye; the score of 2 was assigned to tear secretions with a unilateral eye infection and loss of eye transparency; the score of 3 was assigned to the bilateral ocular discharges. For ear scoring, the score of 0 was assigned to two healthy ears and a normal state, free of any hanging or problematic postures; the score of 1 was assigned to shaking the ear or shaking the head; the score of 2 was assigned to one hanging ear; the score of 3 was assigned to shaking the head vigorously and two hanging ears of the calf. For nasal scores, the score of 0 was assigned to clean and normal nostrils, with colorless and natural moisture; the score of 1 was assigned to low one-side creamy discharge; the score of 2 was assigned to severe bilateral mucus shedding and low two-side creamy discharge; the score of 3 was assigned to severe bilateral purulent discharges from the nose. For cough scoring, the score of 0 was assigned to normal mode; the score of 1 was assigned to single cough; the score of 2 was assigned to consecutive coughs in a short period; the score of 3 was assigned to continuous coughs that interfere with breathing. Finally, for the scratch scoring in the hock joint area, the score of 0 was assigned to the normal condition of the hock joint area, the score of 1 was assigned to untidy hair in the hock joint area, the score of 2 was assigned to untidy hair and 
hair loss in some areas of the hock joint andthe surrounding area; the score of 3 was assigned to intense hair loss so that the skin is directly visible (Rowbotham and Ruegg, 2016).

\section{Blood Immunity Parameters}

To measure blood cells, blood samples were taken from the jugular vein of the calves at 70 days of age under hygienic conditions. Blood samples were transferred to the test tubes containing the anticoagulant EDTA and used for differential counting of white blood cells (heterophils, lymphocytes, monocytes, eosinophils). Giemsa staining technique and light microscope $(E=\times 100)$ were used for this purpose (Leso et al. 2020).

\section{Statistical Analysis of Data}

The collected data were statistically analyzed in a completely randomized design using the general linear model (GLM) and statistical software SAS (2004). The comparison of the means were performed using Duncan's test at $5 \%$ probability level. The statistical model of the design was $Y_{i j}=\mu+A_{i}+e_{i j}$. In this model, $Y_{i j}$ was the value of each observation for the studied trait, $\mu$ was the average of the observations, $A_{i}$ was the effect of experimental treatments and $\mathrm{e}_{\mathrm{ij}}$ was the effect of experimental error.

\section{RESULTS}

The results of the effects of the experimental treatments on calf performance are pre- sented in Table 2. The highest feed intake was related to the sand and chaff beddings and the lowest consumption was related to the mat bedding $(\mathrm{P}<0.05)$. Also, highest weight gain was related to the sand, chaff and straw, whereas the lowest weight gain was related to the bagasse $(\mathrm{P}<0.05)$. The feed conversion ratio of calves on mat bedding was significantly reduced, i.e. improved, compared to the bagasse and sand treatments $(\mathrm{P}<0.05)$.

The results on the effects of the experimental treatments on the skeletal characteristics of the calves are presented in Table 3. Almost no significant effects were found for any period or trait, with the exception of body length at 1 month of age and wither height in the finisher period. After one month, the calves with mat bedding had the lowest body length, which was significantly reduced compared to the other treatments $(\mathrm{P}<0.05)$. At the beginning of the period, the average height from the withers in all groups was 80 to $81 \mathrm{~cm}$, which indicated the uniformity of the cattle $(\mathrm{P}>0.05)$. At one month of age, no significant difference was observed in the height growth of the calves and the calves had a height growth of about 10 to $15 \mathrm{~cm}(\mathrm{P}>0.05)$. At the end of the period, calves under the straw treatment and the mat treatment had the highest and lowest height, with $99.2 \mathrm{~cm}$ and $95.9 \mathrm{~cm}$, respectively, which was a significant difference between the two treatments $(\mathrm{P}<0.05)$.

The results related to the effect of experimental treatments on the behavior of calves are presented in Table 4. The highest feeding time

Table 2. The Effect of Experimental Treatments on Calf Performance

\begin{tabular}{lccccccc}
\hline Performance traits & Chaff & Straw & Bagasse & Sand & Mat & P-value & SEM \\
\hline $\begin{array}{l}\text { Feed Consumption } \\
\text { (kg DM/cow per day) }\end{array}$ & $0.622^{\mathrm{a}}$ & $0.604^{\mathrm{ab}}$ & $0.566^{\mathrm{ab}}$ & $0.655^{\mathrm{a}}$ & $0.523^{\mathrm{b}}$ & 0.031 & 0.04 \\
\hline $\begin{array}{l}\text { Body weight gain } \\
(\mathrm{kg} / \text { cow per day) }\end{array}$ & $0.849^{\mathrm{a}}$ & $0.854^{\mathrm{a}}$ & $0.746^{\mathrm{b}}$ & $0.853^{\mathrm{a}}$ & $0.800^{\mathrm{ab}}$ & 0.028 & 0.03 \\
\hline Feed conversion ratio & $0.73^{\mathrm{ab}}$ & $0.70^{\mathrm{ab}}$ & $0.76^{\mathrm{a}}$ & $0.76^{\mathrm{a}}$ & $0.65^{\mathrm{b}}$ & 0.029 & 0.04 \\
\hline
\end{tabular}

DM: dry matter.

The means within the same row with at least one common letter, do not have a significant difference $(\mathrm{P}<0.05)$.

SEM: standard error of the means. 
was related to the sand treatment, which was significantly different from the chaff, straw, and mat treatments $(\mathrm{P}<0.05)$. The duration of drinking water in the bagasse treatment increased significantly compared to the chaff, straw, and mat treatments $(\mathrm{P}<0.05)$. Also, the longest and shortest sitting time of the calves after milk feeding belonged to the chaff and straw treatments, which were significantly different from the other treatments $(\mathrm{P}<0.05)$.

The resting duration was significantly $(\mathrm{P}<0.05)$ longer in the straw $(21.7 \mathrm{~min})$ than in the sand treatment $(9.1 \mathrm{~min})$. The shortest sitting time belonged to the sand and the longest sitting time belonged to the mat treatment $(\mathrm{P}<0.05)$. The highest licking time among the treatments was related to the straw treatment, which had a significant increase compared to the other treatments $(\mathrm{P}<0.05)$.

The results on the effects of the experi- mental treatments on the health status of the calves are presented in Table 5. The results showed a significant difference in all four stages of cleanness and also in the mean cleanness score for all the experimental treatments, which was the highest numerically, i.e. worst, for the mat treatment $(\mathrm{P}<0.05)$ followed by the sand treatment.

For the nose and eye scores in the first two weeks, mat and sand treatments had the highest values compared with the other treatments $(\mathrm{P}<0.05)$. In the second scoring (after one month), the highest nasal score belonged to chaff and mat, which was significantly different from bagasse treatment $(\mathrm{P}<0.05)$. This situation was slightly different in ocular discharges, so that mat treatment had the highest value compared with chaff, straw, and bagasse $(\mathrm{P}<0.05)$. In the third nasal scoring, the chaff and straw treatments had significant higher values compared to

Table 3. The Effect of Experimental Treatments on the Skeletal Characteristics of Calves

\begin{tabular}{|c|c|c|c|c|c|c|c|}
\hline \multirow{2}{*}{ Parameters } & \multicolumn{5}{|c|}{ Treatments } & \multirow{2}{*}{ P-value } & \multirow{2}{*}{ SEM } \\
\hline & Chaff & Straw & Bagasse & Sand & Mat & & \\
\hline \multicolumn{8}{|l|}{ Body length } \\
\hline Starter period & 65.1 & 65.3 & 61.8 & 63.3 & 66.4 & 0.74 & 2.46 \\
\hline One month of age & $77.5^{\mathrm{a}}$ & $78^{\mathrm{a}}$ & $76.4^{\mathrm{a}}$ & $79.5^{\mathrm{a}}$ & $71.2^{\mathrm{b}}$ & 0.006 & 1.50 \\
\hline Finisher period & 100.8 & 96.8 & 98.7 & 101 & 95.3 & 0.28 & 2.20 \\
\hline \multicolumn{8}{|l|}{ Chest circumference } \\
\hline Starter period & 80.2 & 81.3 & 83 & 81.5 & 81.9 & 0.46 & 1.03 \\
\hline One month of age & 92.3 & 92.3 & 94.9 & 93.5 & 93.4 & 0.35 & 1.02 \\
\hline Finisher period & 110.2 & 110.3 & 109.5 & 112 & 109 & 0.47 & 1.19 \\
\hline \multicolumn{8}{|c|}{ Abdominal circumference } \\
\hline Starter period & 81 & 82.9 & 79.5 & 83.8 & 83.3 & 0.40 & 1.71 \\
\hline One month of age & 93.5 & 96 & 96.3 & 96.9 & 96 & 0.38 & 1.27 \\
\hline Finisher period & 121 & 124.6 & 120.4 & 121.4 & 120.1 & 0.67 & 1.74 \\
\hline \multicolumn{8}{|l|}{$\begin{array}{l}\text { Height from the } \\
\text { withers }\end{array}$} \\
\hline Starter period & 80.6 & 80.3 & 80.1 & 80.1 & 80.1 & 0.97 & 0.693 \\
\hline One month of age & 85.8 & 84.2 & 85.4 & 86 & 84.4 & 0.21 & 0.680 \\
\hline Finisher period & $97.3^{\mathrm{ab}}$ & $99.2^{\mathrm{a}}$ & $96.7^{\mathrm{ab}}$ & $97.9^{\mathrm{ab}}$ & $95.9^{\mathrm{b}}$ & 0.05 & 1.02 \\
\hline \multicolumn{8}{|l|}{ Pelvic width } \\
\hline Starter period & 21 & 20.8 & 20.9 & 21.6 & 21.4 & 0.20 & 0.382 \\
\hline One month of age & 25.4 & 24.9 & 25 & 25.3 & 24.8 & 0.56 & 0.287 \\
\hline Finisher period & 29.3 & 30 & 29.1 & 29.2 & 28.9 & 0.55 & 0.719 \\
\hline
\end{tabular}

The means within the same row with at least one common letter, do not have a significant difference $(\mathrm{P}<0.05)$.

SEM: standard error of the means. 
the mat treatment and in the fourth nasal scoring, the chaff treatment had a significant increase compared to the other treatments, except the sand treatment $(\mathrm{P}<0.05)$. In the third ocular scoring, the bagasse treatment was significantly increased compared to the other treatments $(\mathrm{P}<0.05)$. In the fourth ocular score, the mat and sand treatments had the highest significant differences compared to the other treatments $(\mathrm{P}<0.05)$. The highest mean nasal score was related to the chaff treatment which was significantly different from bagasse treatment $(\mathrm{P}<0.05)$. The highest mean eye scoring was related to mat treatment which was significantly different from the chaff, straw, and bagasse treatments $(\mathrm{P}<0.05)$. No significant differences were observed between the treatments regarding the ear and cough scores $(\mathrm{P}>0.05)$. Also, for the joint score, the mat treatment had the highest significant difference compared to the other treatments $(\mathrm{P}<0.05)$.

The results on the effects of the experimental treatments on the blood immunity parameters of the calves are presented in Table 6 . Among blood cells, there was a significant difference in the treatments only for eosinophils so that bagasse treatment showed the highest difference compared to the other treatments $(\mathrm{P}<0.05)$.

\section{DISCUSSION}

According to the results of the present experiment, the growth rate in the chaff, straw, and sand treatments was higher than in the bagasse treatment. It seems that in the mat treatment, feed intake was lower than the other groups, possibly due to the lower animal comfort, and as a result, consumption was reduced and eventually the animal lost weight (Gascon et al., 2012).

Bagasse, due to its good taste, also caused the animal to refuse to eat feed, which is why bagasse treatment had a significantly lower weight gain than the other treatments (Gascon et al., 2012). The conversion ratio in mat treatment was 0.65 , which was lower (better) than all the other treatments. The conversion ratio of sand and bagasse was 0.76 , which was numerically higher than the other treatments. Studies have shown that conversion ratio alone can be misleading and the final weight gain of calves is more important (Hizli et al., 2018).

Hänninen (2005) stated that the rate of weight gain can be affected by the softness and comfort of the bedding so that more comfortable bedding allows the calf to consume more feed and grow more. In this experiment, calves in the mat treatment also tenden to weigh less than

Table 4. The Effect of Experimental Treatments on the Behavior Characteristics of Calves

\begin{tabular}{|c|c|c|c|c|c|c|c|}
\hline \multirow[b]{2}{*}{ Parameters } & \multicolumn{5}{|c|}{ Treatments } & \multirow[b]{2}{*}{ P-value } & \multirow[b]{2}{*}{ SEM } \\
\hline & Chaff & Straw & $\begin{array}{l}\text { Bagas } \\
\text { se }\end{array}$ & Sand & Mat & & \\
\hline \multicolumn{8}{|l|}{ Nutritional } \\
\hline Feed consumption $(\mathrm{h})$ & $21.7^{\mathrm{cb}}$ & $27.5^{\mathrm{bc}}$ & $30^{\mathrm{ab}}$ & $39.2^{\mathrm{a}}$ & $25^{\mathrm{bc}}$ & 0.04 & 4.04 \\
\hline Drinking water (h) & $1.66^{\mathrm{b}}$ & $0.833^{\mathrm{b}}$ & $6.66^{\mathrm{a}}$ & $2.50^{\mathrm{ab}}$ & $1.66^{\mathrm{b}}$ & 0.01 & 1.87 \\
\hline $\begin{array}{l}\text { Sitting after } \\
\text { milkfeeding }(\mathrm{h})\end{array}$ & $21.8^{\mathrm{a}}$ & $3.33^{\mathrm{c}}$ & $15.16^{\mathrm{b}}$ & $5.00^{\mathrm{c}}$ & $5.33^{\mathrm{c}}$ & 0.002 & 3.52 \\
\hline \multicolumn{8}{|l|}{ Non-nutritional } \\
\hline Sitting Resting (h) & $228^{\mathrm{ab}}$ & $215^{\mathrm{ab}}$ & $237^{\mathrm{ab}}$ & $208^{b}$ & $255^{\mathrm{a}}$ & 0.35 & 13.93 \\
\hline Standing $(\mathrm{h})$ & $161.7^{\mathrm{b}}$ & $148.3^{\mathrm{b}}$ & $129.2^{\mathrm{b}}$ & $168.3^{\mathrm{a}}$ & $148.3^{\mathrm{b}}$ & 0.01 & 37.3 \\
\hline Resting Sitting (h) & $15.8^{\mathrm{ab}}$ & $21.7^{\mathrm{a}}$ & $11.7^{\mathrm{ab}}$ & $6.7^{\mathrm{b}}$ & $9.1^{\mathrm{ab}}$ & 0.01 & 4.89 \\
\hline Licking (h) & $35.8^{\mathrm{b}}$ & $32.5^{\mathrm{a}}$ & $40.8^{\mathrm{b}}$ & $38.3^{\mathrm{b}}$ & $30.0^{\mathrm{b}}$ & 0.01 & 3.30 \\
\hline
\end{tabular}


Table 5. The Effect of Experimental Treatments on the Hygienic Condition of Calves

\begin{tabular}{|c|c|c|c|c|c|c|c|}
\hline \multirow{2}{*}{ Parameters } & \multicolumn{5}{|c|}{ Treatments } & \multirow{2}{*}{ P-value } & \multirow{2}{*}{ SEM } \\
\hline & Chaff & Straw & Bagasse & Sand & Mat & & \\
\hline \multicolumn{8}{|l|}{ Cleanness score } \\
\hline The first score & $0.666^{\mathrm{c}}$ & $0.333^{\mathrm{d}}$ & $0.083^{\mathrm{de}}$ & $1.90^{\mathrm{b}}$ & $2.50^{\mathrm{a}}$ & $<0.001$ & 1.22 \\
\hline The second score & $0.50^{\mathrm{c}}$ & $0.333^{\mathrm{c}}$ & $0^{\mathrm{d}}$ & $1.81^{\mathrm{b}}$ & $2.58^{\mathrm{a}}$ & $<0.001$ & 1.05 \\
\hline The third score & $1^{\mathrm{c}}$ & $0.666^{\mathrm{d}}$ & $0.333^{\mathrm{e}}$ & $2.0^{\mathrm{b}}$ & $3.50^{\mathrm{a}}$ & $<0.001$ & 1.01 \\
\hline The fourth score & $1^{\mathrm{c}}$ & $0.666^{\mathrm{d}}$ & $0.333^{\mathrm{e}}$ & $2.45^{\mathrm{b}}$ & $3.50^{\mathrm{a}}$ & $<0.001$ & 1.07 \\
\hline Average score & $0.791^{\mathrm{c}}$ & $0.50^{\mathrm{c}}$ & $0.187^{\mathrm{d}}$ & $2.06^{\mathrm{b}}$ & $3.02^{\mathrm{a}}$ & $<0.001$ & 1.02 \\
\hline \multicolumn{8}{|l|}{ Eye Score } \\
\hline The first score & $0^{\mathrm{b}}$ & $0^{\mathrm{b}}$ & $0^{\mathrm{b}}$ & $0.454^{\mathrm{a}}$ & $0.416^{\mathrm{a}}$ & 0.002 & 1.02 \\
\hline The second score & $1.6^{\mathrm{bc} 6}$ & $0.166^{\mathrm{bc}}$ & $0^{\mathrm{c}}$ & $0.363^{\mathrm{ab}}$ & $0.50^{\mathrm{a}}$ & $<0.001$ & 0.79 \\
\hline The third score & $0^{\mathrm{c}}$ & $0.166^{\mathrm{bc}}$ & $0.50^{\mathrm{a}}$ & $0.181^{b c}$ & $0.166^{\mathrm{bc}}$ & 0.05 & 0.97 \\
\hline The fourth score & $0.416^{\mathrm{b}}$ & $0.583^{\mathrm{b}}$ & $0.583^{\mathrm{b}}$ & $1.09^{\mathrm{a}}$ & $1.160^{\mathrm{a}}$ & 0.02 & 1.01 \\
\hline Average score & $0.145^{\mathrm{c}}$ & $0.229^{c}$ & $0.270^{\mathrm{bc}}$ & $0.522^{\mathrm{ab}}$ & $0.562^{\mathrm{a}}$ & 0.05 & 0.87 \\
\hline \multicolumn{8}{|l|}{ Ear Score } \\
\hline The first score & 0.166 & 0.83 & 0 & 0.181 & 0.83 & 0.61 & 0.44 \\
\hline The second score & 0.166 & 0.83 & 0 & 0.181 & 0.83 & 0.61 & 0.44 \\
\hline The third score & 0.166 & 0 & 0.83 & 0 & 0 & 0.54 & 0.27 \\
\hline The fourth score & 0.166 & 0 & 0.83 & 0 & 0 & 0.54 & 0.27 \\
\hline Average score & 0.166 & 0.041 & 0.041 & 0.090 & 0.041 & 0.68 & 0.92 \\
\hline \multicolumn{8}{|l|}{ Nose score } \\
\hline The first score & $0^{\mathrm{b}}$ & $0^{\mathrm{b}}$ & $0^{\mathrm{b}}$ & $0.272^{\mathrm{a}}$ & $0.416^{\mathrm{a}}$ & 0.01 & 0.34 \\
\hline The second score & $0.416^{\mathrm{a}}$ & $0.166^{\mathrm{ab}}$ & $0^{\mathrm{b}}$ & $0.181^{\mathrm{ab}}$ & $0.416^{\mathrm{a}}$ & 0.04 & 0.53 \\
\hline The third score & $0.333^{\mathrm{a}}$ & $0.333^{\mathrm{a}}$ & $0.25^{\mathrm{ab}}$ & $0.272^{\mathrm{ab}}$ & $0^{\mathrm{b}}$ & 0.05 & 0.37 \\
\hline The fourth score & $1.00^{\mathrm{a}}$ & $0.583^{\mathrm{b}}$ & $0.166^{\mathrm{c}}$ & $0.818^{\mathrm{ab}}$ & $0.583^{\mathrm{b}}$ & 0.03 & 0.41 \\
\hline Average score & $0.437^{\mathrm{a}}$ & $0.270^{\mathrm{ab}}$ & $0.104^{b}$ & $0.386^{\mathrm{ab}}$ & $0.354^{\mathrm{ab}}$ & 0.05 & 0.42 \\
\hline \multicolumn{8}{|l|}{ Cough score } \\
\hline The first score & 0 & 0 & 0 & 0 & 0 & - & 0 \\
\hline The second score & 0 & 0.181 & 0 & 0 & 0 & 0.37 & 0.01 \\
\hline The third score & 0 & 0.25 & 0 & 0 & 0 & 0.12 & 0.07 \\
\hline The fourth score & 0 & 0.25 & 0 & 0.181 & 0.166 & 0.36 & 0.29 \\
\hline Average score & 0 & 0.166 & 0 & 0.045 & 0.041 & 0.43 & 0.18 \\
\hline \multicolumn{8}{|l|}{ Joint score } \\
\hline The first score & $0^{\mathrm{b}}$ & $0^{\mathrm{b}}$ & $0^{\mathrm{b}}$ & $0.181^{\mathrm{b}}$ & $0.50^{\mathrm{a}}$ & 0.002 & 0.16 \\
\hline The second score & $0.333^{b}$ & $0.333^{\mathrm{b}}$ & $0.166^{\mathrm{b}}$ & $0.181^{\mathrm{b}}$ & $1.66^{\mathrm{a}}$ & 0.004 & 0.38 \\
\hline The third score & $0.166^{\mathrm{c}}$ & $0^{\mathrm{c}}$ & $0^{\mathrm{c}}$ & $0.818^{\mathrm{b}}$ & $3.50^{\mathrm{a}}$ & 0.001 & 0.91 \\
\hline The fourth score & $0.166^{\mathrm{c}}$ & $0^{\mathrm{c}}$ & $0^{\mathrm{c}}$ & $0.818^{\mathrm{b}}$ & $3.50^{\mathrm{a}}$ & $<0.001$ & 0.91 \\
\hline Average score & $0.166^{\mathrm{c}}$ & $0.083^{\mathrm{cb}}$ & $0.041^{\mathrm{c}}$ & $0.50^{\mathrm{b}}$ & $2.29^{\mathrm{a}}$ & $<0.001$ & 0.89 \\
\hline
\end{tabular}

Zero values: means an average score of zero.

The means within the same row with at least one common letter, do not have a significant difference $(\mathrm{P}<0.05)$.

SEM: standard error of the means.

those in the chaff, straw, and sand treatments.

In this study, skeletal growth at the end of the period including body length, chest circumference, abdomen circumference, and pelvic width was not affected by the bedding and no significant difference was seen in them, which is consistent with the results of Sutherland et al.
(2017). Sutherland et al. (2017) showed that cement, gravel, chaff, and debris beddings cannot make a significant difference in calf growth performance. In this experiment, only the height from withers showed a significant difference. The straw treatment with an average of $99.2 \mathrm{~cm}$ had the highest growth and the mat treatment 
Table 6. The Effect of Experimental Treatments on the Blood Immune Parameters of Calves

\begin{tabular}{lccccccc}
\hline \multicolumn{1}{c}{ Parameters } & \multicolumn{5}{c}{ Treatments } & \multirow{2}{*}{ P-value } & SEM \\
\cline { 2 - 6 } \multicolumn{1}{c}{ Sand } & Chaff & Straw & Bagasse & Sand & Mat & & \\
\hline Lymphocytes & 74 & 72.8 & 75.4 & 76 & 77.7 & 0.81 & 2.98 \\
Neutrophils & 26 & 27.1 & 24.4 & 22.3 & 21 & 0.51 & 2.80 \\
Eosinophils & $0.164^{\mathrm{b}}$ & $0.166^{\mathrm{b}}$ & $0.50^{\mathrm{a}}$ & $0.162^{\mathrm{b}}$ & $0.164^{\mathrm{b}}$ & 0.001 & 0.158 \\
Monocytes & 0.500 & 0.750 & 1.08 & 0.500 & 0.25 & 0.41 & 0.468 \\
Basophils & 0.333 & 0.083 & 0.250 & 0.333 & 0.333 & 0.58 & 0.179 \\
\hline
\end{tabular}

The means within the same row with at least one common letter, do not have a significant difference $(\mathrm{P}<0.05)$.

SEM: standard error of the means.

with $95.9 \mathrm{~cm}$ had the lowest growth. Some researchers have stated about the skeletal growth of calves that the more comfortable the calf is on the bedding, the more playful and refreshed the calf will be, and the better the resting, the better the weight gain and growth (Boissy et al., 2007; Sutherland et al., 2017).

Behaviorally, the calves in sand treatment with an average of 208 minutes had the shortest resting time and with 168.3 minutes had the longest standing time, which tallies with the results of Hänninen (2005). Hänninen (2005) stated that this behavior originates from two characteristics of the aeolian sand bedding: the first is that the bedding is cold in winter and the second is the bedding moisture. Also, the aeolian sand treatment showed more hours for feed harvesting, which is probably due to the increase in body temperature in cold conditions. In the straw, bagasse, and chaff treatments, the time that the calves lay on their side on the bedding was longer than the other groups, which indicates the comfort of the animals on the bedding (Camiloti et al., 2012).

Another important point in this area is the duration that the calf tends to sit after consuming milk, because the sooner the calf feels comfortable and sits down, the more it gains weight (Duve and Jensen, 2012). According to the analyzes performed in the chaff and bagasse treatments, the calves sat with a mean of 22 and 15 minutes after milk consumption, respectively, which indicates the comfort of the calf on the bedding of straw and bagasse (Duve and Jensen, 2012). There was also a significant increase in drinking water in the bagasse group, probably due to the taste of the bagasse bedding (Singh et al., 2020).

The results of this study showed that the rate of cough and ear problems in the calves were not affected by the type of bedding. According to research by Sutherland et al. (2014), cleanness scores were not affected by the beddings such as sawdust and rice stalks. Contrary to the mentioned research, in this experiment, there was no significant difference observed on the cleanness score among the beddings. The calves in the mat, sand, chaff, straw, and bagasse treatments had the highest stool contamination scores, respectively.

According to Panivivat et al. (2004), the beddings that transmit contamination and retain less moisture will be the best bedding for calves.

This issue is very important from both health and economic points of view, because the contaminated bedding will cause many infectious problems for livestock, and as a result, the cost of treatment and growth retardation will be the consequences. Economically, in addition to the cost of treatment, there is also the issue of removing the contaminated bed and replacing it (Haley et al., 2001).

The score of nasal discharge in the chaff treatment was significantly higher than the other treatments, which may be due to the presence of fine wood particles in this bedding (Thomsen et al. 2012). However, both sand and mat treatments led to rather high scores. For eye discharges, in general, the best scores belonged to the chaff and straw treatments, while sand and mat 
beddings caused ocular problems in calves, possibly owing to the nasty odor caused by urinary ammonia (Fregonesi et al., 2007). Considering that these two beddings both had the highest percentage in terms of stool contamination (cleanness score), it can be concluded that higher microbial load and more exposure of the calf to infectious agents have a significant effect on the discharges of the nose and eyes (Mattachini et al., 2019). Regarding joint problems, the mat bedding created the most severe degree of problems for livestock, which is consistent with the results of Wolfe et al. (2018). They stated that the farms that used more material for the bedding and had deeper beddings for the livestock showed fewer joint injuries.

According to Roland et al. (2014), bedding has no direct effect on the number of white blood cells in calves. However, in the present experiment, it was found that eosinophils in the two groups of straw and bagasse treatments were significantly different from the other treatments. The researchers stated that the main function of eosinophils in the immune system is to fight parasitic infections and allergies (Majorek et al., 2012; Poorghasemi et al., 2015). Because in the results of the present experiment the reported number for the straw treatment is very small, it is not possible to get an accurate and reliable result. But in the case of bagasse, Gascon et al. (2017) reported that there were allergies as well as ocular and nasal discharges observed in the calves with bagasse bedding. In this study, considering that significant ocular discharges were recorded in the third ocular scoring, this bedding was probably able to cause mild allergies in calves, which caused an increase in eosinophil levels.

\section{CONCLUSION}

The results of the present experiment showed that the mat bedding is not suitable for calf raising in any aspect, because it has negative effects on the calf in terms of comfort, health, and growth performance compared to the other beddings. Straw, bagasse, and sand beddings had the best growth performance, however, bagasse treatment had the lowest growth performance, probably because calves consumed less feed as a consequence of their consuming the bedding, making it not an ideal choice as weight gain is very important. The sand bedding was also excellent in terms of growth, + but did not provide a good hygienic condition for the calves. Finally, straw bedding seems to be ideal bedding for calves, although more research on this subject is necessary.

\section{REFERENCES}

Ahmadi M., A. Ahmadian, M. Poorghasemi, P. Makovicky and A. Seidavi. 2018. Nanoselenium affects on duodenum, jejunum, ileum and coloncharacteristics in chicks: An animal model. Int. J. Nano Dimen. 10 (2): 225-229.

Ahmadi M., M. Poorghasemi, A. Seidavi, E. Hatzigiannakis and C. Milis. 2019. An optimum level of nano-selenium supplementation of a broiler diet according to the performance, economical parameters, plasma constituents and immunity. J. Elementol. 25(3): 1178-1198.

Boissy A. M., G. Manteuffelb, M. BakJensenc, R. O. Moed, B. Spruijte, L. J. Keelingf, C. Wincklerg, B. Forkmanh, I. Dimitrovi, J. Langbeinb, M. Bakkenj, I. Veissiera and A. Aubert. 2007. Assessment of positive emotions in animals to improve their welfare. Physiol. Behav. 92, 375-397.

Boujenane I. 2019. Effects of milking frequency on milk production and composition of Holstein cows during their first three lactations. Iranian J. Appl. Anim. Sci. 9(1), $25-$ 29.

Camiloti T. V., J. A. Fregonesi and D. Weary. 2012. Short communication: Effects of bedding quality. Am. Dairy Sci. Assoc. 4:3380-3383.

Duve L. R. and M. B. Jensen. 2012. Social behavior of young dairy calves housed with limited or full social contact with a peer. J. 
Dairy Sci. 95(10):5936-45.

Eklind Y. and H. Kirchmann. 2000. Composting and storage of organic household waste with different litter amendments. II: nitrogen turnover and losses. Bioresour. Technol. 74:125-133.

Fregonesi J.A., D. M. Veira, von M. A. G. Keyserlingk and D. M. Weary. 2007. Effects of bedding quality on lying behavior of dairy cows. J. Dairy Sci. 90:5468-5472.

Gascon M. K., H. Kromhout, D. Heederik, W. Eduard and B. van Wendel de Joode. 2012. Respiratory, allergy and eye problems in bagasse-exposed sugar cane workers in Costa Rica. Occup. Environ. Med. 69(5), 331-338.

Haley D. B., A. M. de Passillé and J. Rushen. 2001. Assessing cow comfort: effects of two floor types and two tie stall designs on the behaviour of lactating dairy cows. Appl. Anim. Behav. Sci. 71:105-117.

Hänninen, L.D. 2005. The effect of flooring type and social grouping in the rest and growth of dairy calves. Appl. Anim. Behav. Sci. 10:193-204.

Hizli H., T. Ayasan and A. Isik. 2018. Growth performance and survival rate of Southern Anatolian red calves. Iranian J. Appl. Anim. Sci. 8(4):591-595.

Leach K. A., S. C. Archer, J. E. Breen, M. J. Green, I. C. Ohnstad, S. Tuer and A. J. Bradley. 2015. Recycling manure as cow bedding: Potential benefits and risks for UK dairy farms. Vet. J. 206(2):123-130.

Leso L., M. Barbari, M. A. Lopes, F. A. Damasceno, P. Galama, J. L. Taraba and A. Kuipers. 2020. Invited review: Compostbedded pack barns for dairy cows. J. Dairy Sci. 103(2):1072-1099.

Majorek K. A., P. J. Porebski, A. Dayal, M. D. Zimmerman, K. Jablonska, A. J. Stewart, M. Chruszcz and W. Minor. 2012. Structural and immunologic characterization of bovine, horse, and rabbit serum albumins. Mol. Immunol. 52(3-4):174-182.

Mattachini G., J. Pompe, A. Finzi, E. Tullo, E.
Riva and G. Provolo. 2019. Effects of feeding frequency on the lying behavior of dairy cows in a loose housing with automatic feeding and milking system. Animals. 9(4):121-128.

Meng J., F. H. Shi, Q. X. Meng, L. P. Ren, Z. M. Zhou, H. Wu and L. P. Zhao. 2015. Effects of Bedding Material Composition in Deep Litter Systems on Bedding Characteristics and Growth Performance of Limousin Calves. Asian-Australas J. Anim. Sci. 28 (1): 143-150.

Panivivat R.E., E. B. Kegley, J. A. Pennington, D. W. Kellogg and S. L. Krumpelman. 2004. Growth performance and health of dairy. J. Dairy Sci. 87, 3736-3745.

Pirzadeh Naeiny A., M. Danesh Mesgaran, A. R. Vakili and H. Ebrahimi. 2019. Milk production and composition, and intake of Holstein lactating cows fed diets with partial substitution of soybean meal with flaked field pea. Iranian J. Appl. Anim. Sci. 9(1), 45-50.

Poorghasemi M., M. Chamani, S. Z. Mirhosseini, A. A. Sadeghi and A. Seidavi. 2017. Effect of probiotic and different sources of fat on performance, carcass characteristics, intestinal morphology and ghrelin gene expression on broiler chickens. Kaf. Univ. Vet. Fak. Derg. 24(2): 169-178.

Poorghasemi M., A. R. Seidavi, A. A. A. Qotbi, J. R. Chambers, V. Laudadio and V. Tufarelli. 2015. Effect of dietary fat source on humoral immunity response of broiler chickens. European Poult. Sci. 79: 1-8.

Poorghasemi M., A. R. Seidavi, A. A. A. Qotbi, V. Laudadio and V. Tufarelli. 2013. Influence of Dietary Fat Source on Growth Performance Responses and Carcass Traits of Broiler Chicks. Asian-Australasian J. Anim. Sci. 26(5): 705-710.

Rowbotham R.F. and P. L. Ruegg. 2016. Bacterial counts on teat skin and in new sand, recycled sand, and recycled manure solids used as bedding in free stalls. J. Dairy Sci. 99:6594-6608. 
Roland L., Drillich M. and Iwersen M. 2014. Hematology as a diagnostic tool in bovine medicine. J. Vet. Diagn. Invest. 26(5):592 -598 .

Seifzadeh S., M. Ramezani, J. Seifdavati, H. Abdi-Benemar and V. Razmazar. 2019. Effects of weaning age on growth and blood parameters of replacing Holstein calves fed on a restricted step up and down milk feeding program. Iranian J. Appl. Anim. Sci. 9(2), 197-204.

Sharifi M., A. A. Khadem, B. J. Heins, R. Pahlavan, J. Mosavi and M. Safdari. 2017. Effect of forage feeding level on body weight, body condition score, milk production, and milk urea nitrogen of Holstein cows on an organic diet. Iranian J. Appl. Anim. Sci. 9(4), 617-624.

Singh A.K., T. Kumari, M. S. Rajput, A. Baishya, N. Bhatt and S. Roy. 2020. A review: Effect of bedding material on production, reproduction and health and behavior of dairy animals. Int. J. Livest. Res. 10(7):11-20.

Slozhenkina M.I., I. F. Gorlov, O. P. Shakhbazova, R. G. Radjabov, N. V. Ivanova, D.
A. Mosolova, O. A. Knyazhechenko, M. Poorghasemi and A. Seidavi. 2020. Productivity of steers of different genotypes: forecast based on interior indicators. Arq. Bras. Med. Vet. Zootec. 72(6): 2279-2287.

Sutherland M.W., G. M. Worth, C. Cameron, C. M. Ross and D. Rapp. 2017. Health, physiology, and behavior of dairy calves reared on four different substrates. J. Dairy Sci. 100, 1-9.

Thomsen P.T., L. Munksgaard and J. T. Sørensen. 2012. Locomotion scores and lying behaviour are indicators of hoof lesions in dairy cows. Vet. J. 193(3):644-647.

Vasseur E., J. Gibbons, J. Rushen, D. Pellerin, E. Pajor, D. Lefebvre and A. M. de Passillé. 2015. An assessment tool to help producers improve cow comfort on their farms. J. Dairy Sci. 98:698-708.

Wolfe T., V. E. Vasseur, T. J. DeVries and R. Bergeron. 2018. Effects of alternative deep bedding options on dairy cow preference, lying behavior, cleanliness, and teat end contamination. J. Dairy Sci. 101:530 536. 